\title{
Influence of FFF process parameters and macrostructure homogeneity on PLA impact strength (Rapid communication)
}

\author{
Michał Bączkowski ${ }^{1)}$ (ORCID ID: 0000-0002-9717-1046), Dawid Marciniak ${ }^{1), ~ *) ~(0000-0002-0399-3322), ~}$ \\ Marek Bieliński (0000-0002-2867-511X)
}

DOI: dx.doi.org/10.14314/polimery.2021.9.XXX

\begin{abstract}
The article presents studies of the additive manufacturing printing parameters influence on the impact strength of PLA samples obtained by the fused filament fabrication (FFF) method. Two process variables were taken into account in the research program: the height of the printed layer and the printing temperature. An optical microscope was used to analyze the cross-section image (breakthrough) of the samples. The impact strength was determined at $-40^{\circ} \mathrm{C}$ and $23^{\circ} \mathrm{C}$. Selected geometric features of the macrostructure (uniformity and thickness of individual layers, voids) determined on the basis of the sample cross-section image analysis, enhanced the possibility of assessing the PLA impact strength, depending on the adopted process variables and the temperature at which the experiment was carried out.
\end{abstract}

Keywords: PLA, 3D printing, impact strength, process parameters, additive manufacturing.

\section{Wpływ parametrów procesu druku metodą FFF i jednorodności makrostruktury na udarność PLA}

\begin{abstract}
Streszczenie: $W$ artykule przedstawiono badania wpływu parametrów druku addytywnego na udarność próbek z PLA otrzymanych metodą FFF (fused filament fabrication). W programie badań uwzględniono dwie zmienne procesowe: wysokość drukowanej warstwy i temperaturę druku. Do analizy obrazu przełomu próbek wykorzystano mikroskop optyczny. Oznaczono udarność w temperaturze $-40^{\circ} \mathrm{C}$ oraz $23^{\circ} \mathrm{C}$. Wybrane cechy geometryczne makrostruktury (równomierność i grubość poszczególnych warstw, puste przestrzenie) wyznaczone na podstawie analizy obrazu przekroju próbek, pogłębiły możliwość oceny udarności PLA w zależności od przyjętych zmiennych procesowych, a także temperatury w jakiej zrealizowano eksperyment.
\end{abstract}

Słowa kluczowe: PLA, druk 3D. udarność, parametry procesowe, wytwarzanie przyrostowe.

Deposition of plasticized material (FDM/FFF), also known as $3 \mathrm{D}$ printing, belongs to the group of additive manufacturing (AM) techniques. The process is based on extrusion of a plasticized polymer material and selective dosing through a nozzle in order to produce the designed geometry of the final product [1]. Most of the elements printed in the FFF technology are used as prototypes, project visualizations, educational models, but more and more often as ready to use products for utility purposes [2-5]. The growing interest in unit and smalllot production determines the development of this technology, including the design of products for a specific manufacturing technique, e.g. FDM/FFF. This enables

\footnotetext{
1) Bydgoszcz University of Technology, Faculty of Mechanical Engineering, Department of Manufacturing Techniques, Al. Prof. S. Kaliskiego 7, 85-796 Bydgoszcz, Poland.

*) Author for correspondence: dawid.marciniak@utp.edu.pl
}

better use of the advantages as well as reducing the limitations of this technology [6]. Therefore, it becomes necessary to expand the ability to predict the behavior of structural elements in operational conditions. [7]. The parameters of the 3D printing process have the most significant influence on the properties of the manufactured elements in the FDM/FFF technology [8-9]. It is important to determine the relationships between individual printing parameters and their impact on the strength of end elements. Chacon, Caminero, Plaza and Nunez [10] analyzed in their work the influence of the layer height and the printing speed on an element properties. The authors tested 4 different layer heights at 3 different printing speeds, the temperature adopted in the tests was constant, during the arrangement of the paths along the sample longer axis. The authors obtained the best results for the lowest layer height and average print speed. In Behzadnasab and Yousefi paper [11], the authors focused 
on the influence of nozzle temperature on the mechanical properties of additive manufactured parts. PLA samples were produced at four different temperatures, where the lowest temperature was $180^{\circ} \mathrm{C}$, and the highest $240^{\circ} \mathrm{C}$. The highest strength was obtained for samples manufactured at the temperature of $240^{\circ} \mathrm{C}$. Lanzotti, Grasso, Staiano and Martorelli in their work investigated different layer heights and different filling angles of samples made of PLA. The presented research shows that the samples with a $0^{\circ}$ filling angle and a layer height of $0.15 \mathrm{~mm}$ had the highest strength [12]. Wittbrodt and Pearce investigated the effect of nozzle temperature and material color on the mechanical properties of samples printed from PLA. According to the authors, the samples printed at $215^{\circ} \mathrm{C}$ and of natural and black color have the best mechanical properties [13]. The aim of this study is to assess the impact of the layer height and printing temperature, and the temperature at which the tests were carried out, on the samples made of PLA impact strength.

\section{EXPERIMENTAL PART}

\section{Materials and methods}

The test samples were obtained using the Ender 3 PRO machine (Creality, China) in the Fused Filament Fabrication (FFF) technology. Polylactide from Spectrum Group Sp. z o.o. (Poland) with the trade name Premium PLA was used. The beam-shaped samples for measuring the impact strength were made in accordance with EN ISO 179 standard. The following parameters of the additive manufacturing production process were adopted: nozzle diameter: $0.4 \mathrm{~mm}$, printing speed: $60 \mathrm{~mm} / \mathrm{s}$, layer heights: $0.3 \mathrm{~mm}$ and $0.2 \mathrm{~mm}$, nozzle temperature during printing: 195,200 and $205^{\circ} \mathrm{C}$, filling density: $100 \%$, orientation angle of the applied material path relative to the $X$ axis: $0^{\circ}$, number of strokes: 1 . During sample production, a linear fill was used with the orientation of the applied paths parallel to the longer sample axis.

The Charpy impact test was carried out on a pendulum hammer HIT50 (Zwick/Roell, Germany), in accordance with PN EN ISO 179. The impact test was carried out for samples at room temperature and $-40^{\circ} \mathrm{C}$. Preparation of samples for testing at $-40^{\circ} \mathrm{C}$ was carried out using the FRYKA chamber (Zwick/Roell, Germany). In the study of determining the mechanical properties, the number of samples in the measurement series was 5. A high-resolution 4k VHX-7000 digital microscope (Keyence, Japan) was used to analyze the image of the samples fracture structure and to record them.

\section{RESULTS AND DISCUSSIONS}

Figure 1 presents selected cross-sections of samples made in impact tests at a temperature of $-40^{\circ} \mathrm{C}$. It was observed that with the increase of the nozzle temperature, the lateral area of the connection between the individual layers increases, which translates into a decrease in the share of technological voids in the tested samples entire cross-sectional volume. This phenomenon applies to both samples with a layer thickness of $0.2 \mathrm{~mm}$ and $0.3 \mathrm{~mm}$. In the samples with a decrease in the percentage share in the cross-section of technological voids, higher impact load resistance results were obtained.

Table 1 presents the results of the impact strength measurements carried out for samples obtained at the different process variables and the test temperature variable adopted in the program. The observed change in strength, determined under ambient temperature conditions $\left(23^{\circ} \mathrm{C}\right)$, is characterized by an increase of about $7.00 \%$ for samples produced at the nozzle temperature of 195 and $200^{\circ} \mathrm{C}$ and an increase of $12.50 \%$ in the case of samples obtained at the temperature of 195 and $205^{\circ} \mathrm{C}$. This applies to a layer with a thickness of $0.2 \mathrm{~mm}$. In the case of a layer with a thickness of $0.3 \mathrm{~mm}$, these values are higher. Samples obtained at the temperature of $200^{\circ} \mathrm{C}$ have higher impact strength of about $7.69 \%$ then samples created at the temperature of $195^{\circ} \mathrm{C}$ and for samples produced at the temperatures 195 and $205^{\circ} \mathrm{C}$ this difference is $18.93 \%$. When determining the impact strength of samples at a temperature of $-40^{\circ} \mathrm{C}$, a similar effect of the nozzle temperature change on the impact properties of the tested samples can be noticed. In the case of samples with a $0.2 \mathrm{~mm}$ layer, higher results of resistance to impact loads are obtained with increasing printing temperature. The growth rates are in the order of $4.72 \%$ for samples printed at the temperature of 195 and $200^{\circ} \mathrm{C}$ and $10.85 \%$ when the nozzle temperature was 195 and $205^{\circ} \mathrm{C}$.

In the case of the $0.3 \mathrm{~mm}$ layer, these values are respectively $19.66 \%$ when the nozzle temperature was 195 and

T a b l e 1. The impact strength of PLA samples

\begin{tabular}{|c|c|c|c|}
\hline \multirow{2}{*}{ Layer thickness, mm } & \multirow{2}{*}{ Nozzle temp., ${ }^{\circ} \mathrm{C}$} & \multicolumn{2}{|c|}{ Impact strength, $\mathrm{kJ} / \mathrm{m}^{2}$} \\
\hline & & at $23^{\circ} \mathrm{C}$ & at $-40^{\circ} \mathrm{C}$ \\
\hline 0.2 & 195 & $20.0 \pm 5.6$ & $21.2 \pm 5.2$ \\
\hline 0.2 & 200 & $21.4 \pm 2.4$ & $22.2 \pm 2.8$ \\
\hline 0.2 & 205 & $22.5 \pm 2.6$ & $23.5 \pm 1.4$ \\
\hline 0.3 & 195 & $16.9 \pm 6.0$ & $11.7 \pm 3.1$ \\
\hline 0.3 & 200 & $18.2 \pm 1.5$ & $14.0 \pm 0.7$ \\
\hline 0.3 & 205 & $20.1 \pm 0.7$ & $15.0 \pm 1.7$ \\
\hline
\end{tabular}




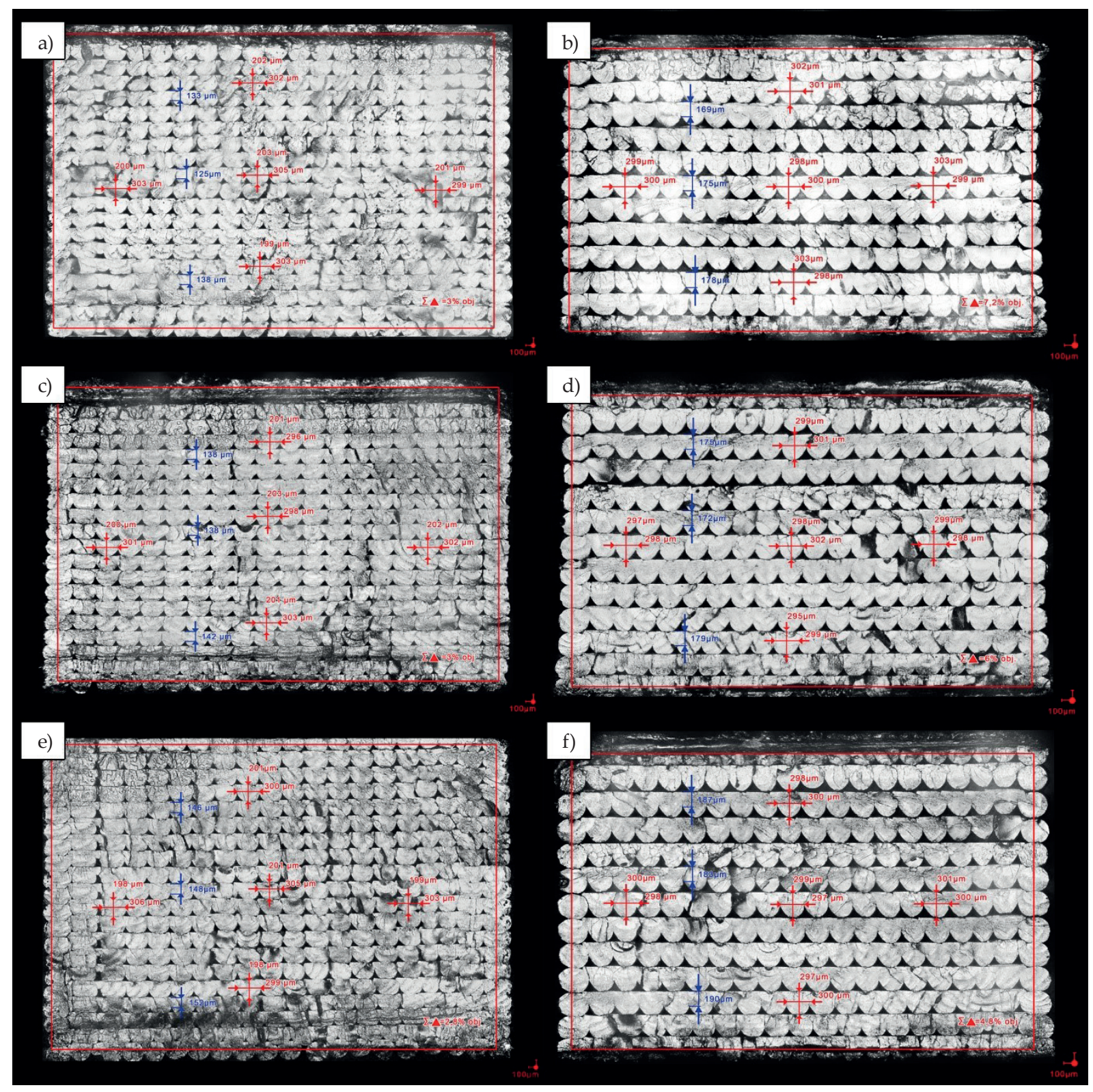

Fig. 1. Examples of sample breakthroughs after the conducted impact tests: a) $0.2 \mathrm{~mm}$ layer, nozzle temperature $195^{\circ} \mathrm{C}$, b) $0.3 \mathrm{~mm}$ layer, nozzle temperature $195^{\circ} \mathrm{C}$, c) $0.2 \mathrm{~mm}$ layer, nozzle temperature $\left.200^{\circ} \mathrm{C}, \mathrm{d}\right) 0.3 \mathrm{~mm}$ layer, nozzle temperature $200^{\circ} \mathrm{C}$, e) $0.2 \mathrm{~mm}$ layer, nozzle temperature $\left.205^{\circ} \mathrm{C}, \mathrm{f}\right) 0.3 \mathrm{~mm}$ layer, nozzle temperature $205^{\circ} \mathrm{C}$

$200^{\circ} \mathrm{C}$ and $28.21 \%$ for samples printed at the temperature of 195 and $205^{\circ} \mathrm{C}$.

From the analysis of the results presented in Table 1, it can be observed that the samples tested at $-40^{\circ} \mathrm{C}$ and build from the $0.3 \mathrm{~mm}$ layers have significantly lower impact strength in relation to the other results, especially the samples tested at $23^{\circ} \mathrm{C}$.

As shown in Figure 2, an increase in the impact strength determined at $-40^{\circ} \mathrm{C}$ for the samples consisting of $0.2 \mathrm{~mm}$ layers for all nozzle temperature values was noted, as well as significant decrease in impact strength at the negative temperature for prints with a layer height of $0.3 \mathrm{~mm}$. The average value of the impact at $23^{\circ} \mathrm{C}$ for the samples with the $0.3 \mathrm{~mm}$ layer produced at the temperatures of 195 and $200^{\circ} \mathrm{C}$ was $15 \%$ lower than for the samples with the $0.2 \mathrm{~mm}$ layer and samples with a $0.3 \mathrm{~mm}$

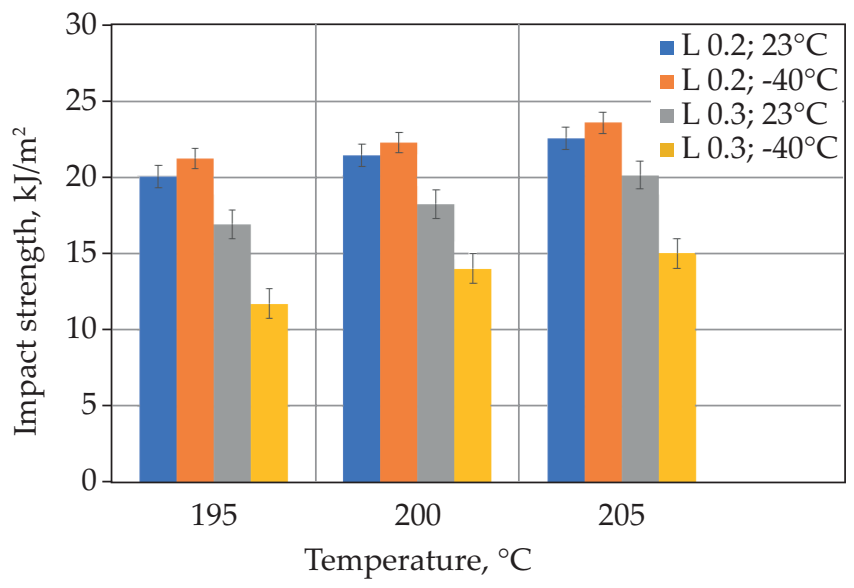

Fig. 2. Results of the impact strength measurement of polylactide samples printed in the FFF technology 
layer produced at $205^{\circ} \mathrm{C}$ were $11 \%$ weaker than those with a $0.2 \mathrm{~mm}$ layer. For samples tested at $-40^{\circ} \mathrm{C}$ differences were significantly larger. The average value of the impact strength for the samples with the $0.3 \mathrm{~mm}$ layer produced at the temperature of $195^{\circ} \mathrm{C}$ was $45 \%$ lower than for the samples with the $0.2 \mathrm{~mm}$ layer and the average value of the impact strength for the samples with the $0.3 \mathrm{~mm}$ layer produced at the temperatures of 200 and $205^{\circ} \mathrm{C}$ was about $36 \%$ lower than for the samples with the $0.2 \mathrm{~mm}$ layer. A significant reduction in the impact strength for samples with the $0.3 \mathrm{~mm}$ layers may result from a bigger share of technological voids in the obtained sample cross-section and a smaller fusion area between individual material paths.

\section{CONCLUSIONS}

The tests confirmed a significant contribution of the layer height to the impact strength of PLA samples, therefore it is recommended to use lower layers in elements manufactured with additive technologies in case of the need to increase the mechanical strength.

A decrease in mechanical strength was demonstrated, determined at negative temperature in the case of samples with a layer height of $0.3 \mathrm{~mm}$.

Based on the analysis of the cross section macrostructure, it was found that the increase of the nozzle temperature during printing process enlarges the side edge of adjoining adjacent layers, thus improving the samples mechanical properties.

The analysis of the obtained breakthroughs image shows the need to search for such technological parameters that will enable the minimization of technological voids in the internal structures of products. This is expected to result in a further increase in the mechanical strength of additive manufactured structures.

\section{REFERENCES}

[1] Shahrubudin N., Lee T.C., Ramlan R.: Procedia Manufacturing 2019, 35, 1286.

https://doi.org/10.1016/j.promfg.2019.06.089

[2] Kopowski J., Rojek I., Mikołajewski D., Macko M.: Advances in Manufacturing II 2019. https://doi.org/10.1007/978-3-030-18715-6_25

[3] Marciniak D., Czyżewski P., Sykutera D., Bieliński M.: 2021. Polimery 2019, 64(11-12), 803. https://doi.org/10.14314/polimery.2019.11.9

[4] Sampaio Á.M., Pontes A.J.: Networks and Systems 2021, 274. https://doi.org/10.1007/978-3-030-80462-6_8

[5] Saleh Alghamdi S., John,S., Roy Choudhury N., Dutta N.K.: Polymers 2021, 13, 753. https://doi.org/10.3390/polym13050753

[6] Marciniak D., MATEC Web Conf., 332, 2021, 01010. https://doi.org/10.1051/matecconf/202133201010

[7] Shanmugam V., Das O., Babu K. et al.: International Journal of Fatigue 2021, 143, 106007. https://doi.org/10.1016/j.ijfatigue.2020.106007.

[8] Piedra-Cascón W., Krishnamurthy V.R., Att W., Revilla-León M.: Journal of Dentistry 2021, 109, 103630. https://doi.org/10.1016/j.jdent.2021.103630.

[9] Hossain M.S., Ramos J., Espalin D.: Solid Freeform Fabrication Symposium, University of Texas, 2013, p. 380.

[10] J. Chacon, M. Caminero, E. Plaza, P. Nunez. Materials and Design, 124, 143-157, 2017

[11] M. Behzadnasab, A. Yousefi. $12^{\text {th }}$ International Seminar on Polymer Science and Technology, Islamic Azad University, Tehran, Iran, 2016.

[12] A. Lanzotti, M. Grasso, G. Staiano, M. Martorelli. Rapid Prototyping Journal 2015, 21, 5, 604. https://doi.org/10.1108/RPJ-09-2014-0135

[13] B. Wittbrodt, J. Pearce: Additive Manufacturing 2015, 8, 110.

Received .... 2021. 